\title{
PENERAPAN METODE THE LEARNING CELL BERBANTU MEDIA POP-UP STORY BOOK UNTUK MENINGKATKAN HASIL BELAJAR IPS KELAS V SDN CANDI O1 SEMARANG
}

\author{
Wahyu Dwi Martiningdyah
}

Surel:wmartiningdyah@gmail.com

\begin{abstract}
This study aims to improve the learning outcomes of IPS with the application of the method of learning cell learning media pop-up story booksiswa class $V$ SD Negeri Candi 01 Semarang. The research method is quantitative with Pre-Experimental Design type one group pretest-postest design. The subjects were 24 students. Data analysis techniques used are qualitative description and quantitative description. The result of the research shows that there is an increase of IPS learning result through thelearning cell method using pop-up story book media in class $V$ students. Based on field observation, the average of students' learning outcomes before treatment is $\leq 50 \%$, and the expected result after treatment is $\geq 75 \%$.
\end{abstract}

Keywords: The Learning Cell, Learning Outcomes, Pop-Up Story Book

\begin{abstract}
ABSTRAK
Penelitian ini bertujuan untuk meningkatkan hasil belajar IPS dengan penerapan metode the learning cell berbantu media pop-up story booksiswa kelas V SD Negeri Candi 01 Semarang. Metode penelitian adalah kuantitatif dengan desain Pre-Experimental Design jenis one group pretest-postest design. Subjek penelitian adalah 24 siswa. Teknik analisis data yang digunakan yaitu deskripsi kualitatif dan deskripsi kuantitatif. Hasil penelitian menunjukkan adanya peningkatan hasil belajar IPS melalui metode thelearning cell berbantu media pop-up story book pada siswa kelas V. Berdasarkan observasi lapangan rata-rata hasil belajar siswa sebelum perlakuanadalah $\leq 50 \%$, dan hasil yang diharapkan setelah diberikan perlakuan adalah $\geq 75 \%$.
\end{abstract}

Kata Kunci: The Learning Cell, Hasil Belajar, Pop-Up Story Book

\section{PENDAHULUAN}

IPS merupakan salah satu mata pelajaran yang wajib diberikan di sekolah dasar yang menggunakan Kurikulum Tingkat Satuan Pendidikan (KTSP). Mata pelajaran IPS, merupakan pelajaran yang materinya dikembangkan dari aspekaspek dalam kehidupan nyata.
Menurut Moeljono Cokrodikardjo dalam Rachmawati (2014:3), IPS adalah perwujudan dari suatu pendekatan interdisiplin dari ilmu sosial (sosiologi, antropologi budaya, psikologi, sejarah, geografi, ekonomi, ilmu politik dan ekopologi manusia).

Sedangkan Somantri dalam Sapriya (2016:11) pendidikan IPS

Jurusan PGSD FIP Universitas PGRI Semarang 
adalah penyederhanaan dari disiplin ilmu sosial dan kemanuasiaan serta kegiatan-kegiatan manusia yang mendasar yang disajikan secara ilmiah untuk tujuan pendidikan. Namun jika materi pelajaran IPS diberikan dengan cara yang kurang tepat, seperti dengan menerapkan metode pembelajaran yang sederhana, akan hanya sedikit menarik perhatian siswa.

Berdasarkan presentase ketuntasan nilai siswa kelas V SD Negeri Candi 01 Semarang yang mencapai $45 \%$ dengan nilai KKM 70 pada Ulangan Tengah Semester, membuktikan bahwa pola pembelajaran yang diterapkan guru kurang sesuai dengan karakteristik siswa. Oleh sebab itu guru seharusnya menerapkan metode terbaru dan menggunakan bantuan media pembelajaran untuk menunjang terjadinya komunikasi yang positif antara guru dengan siswa dan sebaliknya. Dengan begitu pembelajaran juga terkesan menyenangkan sehingga mempermudah pemahaman siswa dalam memahami materi dan hasil belajar IPS siswa meningkat.

Menurut Sudjana (2005: 76) metode mengajar adalah suatu alat yang diciptakan oleh guru untuk menunjang proses kegiatan belajar mengajar sehingga terjadi interaksi edukatif. Pemilihan metode pembelajaran harus benar-benar selektif, media yang layak adalah yang mencakup proses yang mampu melatih siswa bekerjasama dalam memahami materi sehingga dapat mempermudah siswa untuk menyelesaikan permasalahan yang dihadapi dalam tugas yang didapat dari guru, merangsang keaktifan siswa dalam proses belajar mengajar, memberikan rasa percaya diri untuk berbicara di depan kelas serta dapat menuliskan hasil kerjasama dengan pasangannya di depan kelas sehingga memunculkan semangat berkompetisi antar siswa. Dengan adanya hal tersebut kegiatan belajar mengajar menjadi aktif. Tidak ada siswa yang melakukan aktivitas di luar kegiatan pembelajaran. Untuk itu dipilih metode the learning cell yang termasuk model pembelajaran kooperatif dalam bentuk berpasangan dimana perencanaan pembelajarannya dari tindakan yang cermat, dimana siswa bertanya dan mmenjawab pertanyaan secara bergantian berdasarkan materi bacaan yang sama (Suprijono, 2016: 141).

Dengan karakteristik pelajaran IPS yang merupakan penjabaran dari aspek-aspek kehidupan, akan membosankan jika penggunaan metode tidak disertai dengan penggunaan media pembelajaran. Menurut Hanafiah dan Cucu Suhana (2012: 59) media pembelajaran merupakan segala bentuk perangsang dan alat yang disediakan guru untuk mendorong siswa belajar secara cepat, tepat, mudah, benar dan tidak terjadinya verbalisme. Media pembelajaran merupakan alat bantu 
pendengaran dan penglihatan (Audio Visual Aid) bagi peserta didik dalam rangka memperoleh pengalaman belajar secara signifikan.

Salah satu media yang dapat mempermudah anak untuk berimajinasi ke masa lalu dan mengingatkan segala peristiwa yang terjadi adalah media pop-up story book. Media tiga dimensi ini sangat menarik bagi siswa karena bentuk yang unik dan kejutan saat membuka setiap halamannya selalu dinantikan oleh siswa.

Menurut Barton Carol (1998:1) pop up disebut juga dengan paper engineering, merupakan the art of mechanizing paper. It encompasses the design of three dimensional paper forms which are folded flat between a closed page spread and pop-up with the action of opening the page. Paper engineering also covers the design of mechanisms such as pull tabs and rotating wheels whose movement is activated by the reader or viewer.

Berdasarkan uraian di atas dapat disimpulkan bahwa pop-up book adalah media buku yang memiliki bentuk tiga dimensi sehingga dapat terlihat hidup. Hal tersebut dapat terjadi karena adanya teknik dalam mekanisasi kertas yaitu berupa keterampilan melipat potongan kertas. Keterampilan itulah yang dapat dilihat ketika pop-up book dibuka dan halaman tersebut akan bergerak.

Dalam penelitian ini peneliti ingin memberikan sedikit perubahan pada pop-up yang umum dijumpai dengan memberikan penambahan cerita atau story agar pop-up yang dimaksud dapat terbaca tanpa pengarahan atau petunjuk dari moderator. Peneliti akan mendemonstrasikan pop-up dengan tujuan agar siswa dapat melihat ilustrasi yang hampir sama dengan kejadian sebenarnya lewat penegasan story yang telah dituliskan dalam popup tersebut.

Berdasarkan dari permasalahan di atas, maka tujuan yang akan dicapai dalam penelitian ini yaitu meningkatkan hasil belajar Ilmu Pengetahuan Sosial (IPS) kelas V SD Negeri Candi 01 Semarang dengan menggunakan metode the learning cell berbantu media pop up story book.

\section{METODE PENELITIAN}

Jenis penelitian ini adalah penelitian kuantitatif. Subjek penelitian ini adalah siswa kelas $\mathrm{V}$ SD Negeri Candi 01 Semarang tahun ajaran 2015/ 2016 sebanyak 24 siswa. Objek dalam penelitian ini adalah peningkatan hasil belajar IPS.

Penelitian ini dilaksanakan di SD Negeri Candi 01 Semarang beralamatkan di jalan Mataram nomor 827, Candisari, Semarang. Waktu penelitian dilakukan pada semester genap. 
Teknik Pengumpulan Data

1. Observasi

$$
\text { Jenis observasi yang }
$$

dilakukan pada penelitian ini adalah observasi sistematis, yaitu observasi yang dilakukan oleh pengamat dengan menggunakan pedoman sebagai instrumen pengamatan. Observasi dilakukan untuk memperoleh data tentang proses pembelajaran yang terjadi di kelas secara langsung.

2. Wawancara

$$
\text { Pada }
$$

penelitian inimenggunakan jenis wawancara terpimpin, yaitu wawancara yang dilakukan oleh pewawancara dengan membawa sederetan pertanyaan lengkap dan terperinci. Wawancara dilakukan kepada guru kelas V SD Negeri Candi 01 Semarang untuk memperoleh informasi, dan penjelasan implementasi pembelajaran IPS di kelas V SD Negeri Candi 01 Semarang.

\section{Tes}

Peneliti akan memberikan tes berupa pretest dan posttest yang tujuannya untuk mengukur kemampuan awal dan akhir siswa, sehingga keberhasilan penelitian ini akan terlihat.

4. Dokumentasi

Dokumentasi digunakan untuk memberikan gambaran secara kongkret kegiatan yang terjadi dalam pembelajaran berlangsung serta untuk memperkuat data yang telah diperoleh dalam penelitian. Dokumentasi dalam penelitian ini berupa RPP, lembar observasi guru, lembar observasi hasil belajar siswa, pedoman wawancara dan foto.

\section{Teknik Analisis Data \\ Penelitian ini menggunakan teknik analisis data deskripsi} kualitatif dan deskripsi kuantitatif. Dalam penelitian ini, analisis data dimulai sejak awal sampai akhir pengumpulan data. Data yang terbentuk kata-kata atau kalimat dari hasil observasi diolah menjadi kalimat-kalimat yang bermakna dan dianalisis secara kualitatif. Analisis data ini kemudian dikerjakan secara intensif sesudah penelitian selesai. Disamping berbentuk kualitatif, data yang diperoleh dari penelitian ini juga berbentuk data deskripsi kuantitatif yang berupa angka-angka sederhana yang diperoleh dari hasil perhitungan lembar observasi pada saat tindakan dilakukan dan disajikan dalam bentuk terstruktur sehingga mudah dipahami.

Analisis data kualitatif digunakan untuk memperoleh data persentase rata-rata (mean) dari hasil tes siswa pada saat tindakan dilakukan. Rata-rata nilai tes siswa dapat dihitung dengan rumus:

$$
M_{x}=\frac{\Sigma \mathrm{x}}{N}
$$


Keterangan:

$\mathrm{Mx}=$ mean yang dicari

$\Sigma \mathrm{x}=$ jumlah dari nilai-nilai yang ada

$\mathrm{N}=$ banyaknya nilai-nilai itu sendiri

Hasil belajar memiliki Kriteria Ketentuan Minimal (KKM) yang harus dicapai siswa. Untuk nilai hasil belajar kognitif pada mata pelajaran IPS di SDN Candi 01 Semarang nilai KKMnya adalah 70. Jika nilai ratarata pada posteset telah mencapai nilai minimal atau telah mencapai nilai Kreteria Ketentuan Minimal (KKM) 70 setelah pembelajaran melalui metode the learning cell berbantuan media pop up story book maka pembelajaran dikatakan berhasil.

Menghitung persentase ketuntasan belajar yang telah dicapai oleh siswa digunakan rumus

$$
p=\frac{f}{N} x
$$

Keterangan:

$\mathrm{f}=$ frekuensi yang sedang dicari persentasenya

$\mathrm{N}=$ jumlah frekuensi atau banyaknya individu

$\mathrm{P}=$ angka persentase

Menurut pedoman di atas didapatkan data perbandingan nilai rata-rata pada persentase siswa yang nilainya di atas KKM. Jika nilai ratarata postest lebih besar daripada nilai pretest, maka dapat kesimpulan bahwa hasil belajar IPS siswa kelas V SDN Candi 01 Semarang.
Hipotesis statistik yang diajukan dalam penelitian adalah sebagai berkut:

Ho : tidak ada perbedaan antara nilai pretest dan posttest dalam penerapan metode pembelajaran the learning cell berbantu media pop up story book terhadap hasil belajar IPS siswa kelas V SDN Candi 01 Semarang dengan $t_{\text {hitung }}<\mathrm{t}_{\text {tabel }}$.

$\mathrm{Ha}$ : ada perbedaan antara nilai prestest dan posttest dalam penerapan pembelajaran the learning cell berbantu media pop up story book terhadap hasil belajar IPS siswa kelas V SDN Candi 01 Semarang thitung $>$ $t_{\text {tabel. }}$

\section{HASIL DAN PEMBAHASAN}

Penelitian ini merupakan jenis penelitian kuantitatif yang bertujuan untuk meningkatkan hasil belajar siswa kelas V SD Negeri Candi 01 Semarang. Kegiatan pembelajaran yang dilaksanakan dinyatakan berhasil jika terjadi perubahan proses yang ditunjukkan dengan adanya peningkatkan hasil belajar IPS oleh siswa. Oleh karena itu, indikator keberhasilan penelitian ini ditandai dengan adanya peningkatan hasil belajar siswa lebih dari atau sama dengan $\geq 75 \%$ dari seluruh siswa tuntas belajar, yakni memperoleh nilai minimal 70 pada aspek kognitif setelah melaksanakan pembelajaran dengan menggunakan metode the learning cell berbantuan media pop up story book sesuai KKM mata 
pelajaran IPS di SD Negeri Candi 01 Semarang.

\section{SIMPULAN}

Dengan demikian salah satu upaya untuk meningkatkan hasil belajar IPS siswa kelas V SD Negeri Candi 01 Semarang adalah dengan penerapan metode the learning cellberbantu media pop-up story book.

Berdasarkan hasil analisis, ratarata nilai IPS yang didapat siswa lebih dari atau sama dengan (>) 75\% dari seluruh siswa tuntas belajar, yakni memperoleh nilai minimal 70. Hal tersebut menunjukkan bahwa terdapat perbedaan nilai yang signifikan antara nilai pretest dan postest. Jadi dapat disimpulkan bahwa ada perbedaan antara nilai prestest dan posttest dalam penerapan pembelajaran the learning cell berbantu media pop up story book terhadap hasil belajar IPS siswa kelas V SDN Candi 01 Semarang $t_{\text {hitung }}>t_{\text {tabel }}$.

\section{DAFTAR RUJUKAN}

Barton, Carol. 1998. Paper Engineering and Pop-Up Demonstration. True Line Dies: New York.

Hanafiah \& Cucu S. 2012. Konsep Srategi Pembelajaran. Bandung: Refika Aditama.

Rachmawati H. 2014. Penggunaan Media Gambar Alam Sekitar Untuk Meningkatkan Keterampilan Berbicara Siswa Kelas I SDN Ploso V-176
Surabaya. Jurnal. PGSD FIP Universitas Negeri Surabaya.

Sapriya. 2016. Pendidikan IPS Konsep Dan Pembelajaran. Bandung: Remaja Rosdakarya.

Sudjana, Nana. 2005. Dasar-Dasar Proses Belajar Mengajar. Bandung: Sinar Baru Algensindo.

Suprijono, Agus. 2016. Cooperative Learning Teori \& Aplikasi Paikem. Yogyakarta: Pustaka Pelajar. 